\title{
Platelet adhesiveness in gout
}

\author{
L. Gail Darlington \\ M.B.,B.S.
}

J. T. SCOTT
M.D., F.R.C.P.

\author{
SiDNEY SHAW \\ M.D., F.R.C.Path.
}

\section{Summary}

Platelet adhesiveness studies were performed by two techniques in twenty-two gout patients and closely matched controls under carefully standardized conditions. No significant difference in platelet adhesiveness was found between the groups.

A RANGE of plasma lipid levels was recently investigated in twenty-two adult British gout patients and in twenty-two very closely-matched controls, who were hospital patients suffering from a wide variety of conditions. The results of this study have been presented (Darlington, Shaw \& Scott, 1971; Darlington \& Scott, 1972). Summarized, they showed no significant difference between plasma cholesterol levels, but significantly higher levels of plasma glycerides and phospholipids $(0.01>P>0.001)$ and very significantly higher levels of plasma unesterified fatty acids in the gout patients $(P<<0.001)$ (Table 1).

TABle 1. Summary of statistics of lipid studies in twentytwo gout patients and twenty-two controls

\begin{tabular}{lll}
\hline & \multicolumn{1}{c}{$t$} & \multicolumn{1}{c}{$P$} \\
\hline Cholesterol-gout vs controls & 1.260 & $>0.2,<0.3$ \\
Glycerides-gout vs controls & 3.15 & $>0.001,<0.01$ \\
Phospholipids-gout vs controls & $2.966>0.001,<0.01$ \\
UFA-gout vs controls & $4.530<<0.001$ \\
\hline
\end{tabular}

Kerr et al. (1965) found that certain phospholipid fractions and free fatty acids caused platelet aggregation; a result confirmed with regard to fatty acids by Hoak, Warner \& Connor (1967).

Because of increased levels of phospholipids and unesterified fatty acids in gout patients, and because it has been suggested that there is a high incidence of cardiovascular disease in gout (Weiss \& Segaloff, 1959; Hall, 1965), platelet adhesiveness studies have been performed in the gout patients and controls from the study of Darlington et al. (1971), and the results are now presented.
Patients, methods and related factors

Two techniques were performed in parallel, using whole blood and platelet-rich plasma, by the or method of Shaw, Pegrum \& Wolff (1970). In this $\stackrel{9}{-}$ method, blood and platelet-rich plasma were passed is through a standard column of glass microspherules at a constant rate. Adenosine diphosphate was added to the platelet-rich plasma before passage $\vec{C}$ through the column. Platelet adhesiveness was obtained by taking the difference between the platelet count before and after passage through the column 2 and expressing it as a percentage of the initial coung $\overrightarrow{0}$ Factors affecting the test conditions, blood sample $\omega$ and the state of the patient were carefully stanis ardized as follows: (1) All subjects had fasted for least $10 \mathrm{hr}$ before the test, to give a result in the fasting state and to reduce variables of intestinal absorption. Ingestion of glucose and fat increase platelet adhesiveness (Bridges et al., 1965; McDonald \& Edgill, 1958). (2) Adhesiveness was determined within 1-2 $\mathrm{hr}$ of taking blood, since the time interval after venepuncture is important (Fyfe \& Hamilton, 1967). (3) Patients were asked not to smoke for at least $9 \frac{1}{2} \mathrm{hr}$ before the test since smoking has variable effects which may cause platelet adhesiveness to be affected by fatty acids and glucose in the plasma (Murchison \& Fyfe, 1966). (4) No patient or control was receiving aspirin therapy and all subjects were asked to avoid this drug before the test. Aspirin may affect several tests of platelet activity (O'Brien, 1968a) and it appears that, in most circumstances, ADP is not released from platelets exposed to aspirin (O'Brien, 1968b). (5) No patient or control was on any drug known to affect plasma lipids or platelet adhesiveness. (6) Patients were seen early in the morning when exercise had been minimal but accurate assessment of the amount of exercise was nevertheless difficult. Acute, exhaustive exercise increases platelet adhesiveness (Ikkala, Myllylä \& Sarajas, 1966) but severe, prolonged exercise caused a fall in platelet adhesiveness (Pegrum et al., 1967). 
Following the initial work of Wright (1942), many workers have recorded variations in platelet adhesiveness after surgery and, hence, no abnormal platelet adhesiveness result was accepted until three months or more had elapsed after any trauma or surgery.

Since the work was carried out under the standardized conditions laid down by Shaw et al. (1970) and in the same laboratory, their normal values for healthy blood donors were used to give the ranges of normal platelet adhesiveness for whole blood and platelet-rich plasma, i.e. $35-72 \%$ and $19-65 \%$ respectively.

\section{Results}

The platelet adhesiveness values obtained are summarized in Table 2. A regression analysis was performed to determine the significance of these results and is summarized in Table 3. This analysis showed no significant difference in platelet adhesiveness between gout patients and controls by either technique $(P>>0 \cdot 1)$.

TABLE 2. Comparison of platelet adhesiveness between gout patients and controls

\begin{tabular}{lcc}
\hline & \multicolumn{3}{c}{ Mean \pm SD } \\
\cline { 2 - 4 } & Whole blood (\%) & Plasma (\%) \\
\hline $\begin{array}{l}\text { Gout patients } \\
\text { Controls }\end{array}$ & $\begin{array}{l}52 \cdot 2 \pm 12 \cdot 8 \\
51 \cdot 8 \pm 13 \cdot 6\end{array}$ & $\begin{array}{l}30 \cdot 3 \pm 12 \cdot 7 \\
25 \cdot 4 \pm 8 \cdot 0\end{array}$ \\
\hline \multicolumn{4}{c}{ TABLE 3. } & Regression analysis \\
\hline \multicolumn{4}{c}{ Cofficient of } \\
\hline $\begin{array}{l}\text { Gout patients vs controls } \\
\text { by whole blood technique }\end{array}$ & $-0 \cdot 177 \quad>>0 \cdot 1$ \\
$\begin{array}{c}\text { Gout patients vs controls } \\
\text { by plasma technique }\end{array}$ & $-0 \cdot 181 \quad>>0 \cdot 1$ \\
\hline
\end{tabular}

Significant correlation between the two techniques was found for both the gout patients and the controls with $r=0.354$ and 0.407 respectively and $0.02 \geqslant P>0.01$ (Table 4). This agrees reasonably with the results of Shaw et al. (1970) who found a coefficient of correlation, $r$ of 0.46 between the results from the two methods with $P=0 \cdot 001$.

\begin{tabular}{|c|c|c|}
\hline Group & $r$ & $P$ \\
\hline $\begin{array}{l}\text { Control } \\
\text { Gout }\end{array}$ & $\begin{array}{l}-0.407 \\
-0.354\end{array}$ & $\begin{array}{l}>0.01,<0.02 \\
>0.01,<0.02\end{array}$ \\
\hline
\end{tabular}

Since exercise affects platelet adhesiveness it was necessary to ensure that mobility was not having a significant effect on the results obtained by either technique. The gouit and control subjects were divided into two groups - those who were mobile and had been bled as out-patients and those who were immobile in-patients.

The results are summarized in Tables 5 and 6, and show that mobility did not significantly affect the results. There was, however, a very significant difference between platelet adhesiveness measurements by the whole blood and the plasma techniques, in both mobile and immobile subjects.

\section{Discussion}

This study has demonstrated that the hyperlipidaema present in many patients with gout is not associated with increased platelet adhesiveness, since this did not differ between groups of gout patients and control subjects, as measured by two different methods. Some of the gout patients were taking treatment which was lowering the plasma concentration of uric acid (uricosuric agents or allopurinol),

TABLE 5. Statistics to assess the effect of mobility on platelet adhesiveness

\begin{tabular}{|c|c|c|c|c|c|c|c|}
\hline & \multicolumn{2}{|c|}{ Mobile patient } & \multicolumn{2}{|c|}{ Immobile patient } & \multirow[b]{2}{*}{$\begin{array}{c}\text { Combined } \\
\text { SD }\end{array}$} & \multirow[b]{2}{*}{$t$} & \multirow[b]{2}{*}{$P$} \\
\hline & Mean & Variance & Mean & Variance & & & \\
\hline $\begin{array}{l}\text { Whole blood } \\
\text { Plasma }\end{array}$ & $\begin{array}{l}51 \cdot 47 \\
29 \cdot 8\end{array}$ & $\begin{array}{l}165 \cdot 8 \\
146 \cdot 5\end{array}$ & $\begin{array}{l}51 \cdot 5 \\
24 \cdot 15\end{array}$ & $\begin{array}{l}195 \\
50.97\end{array}$ & $\begin{array}{l}13 \cdot 2 \\
10 \cdot 89\end{array}$ & $\begin{array}{l}0.0011 \\
1.56\end{array}$ & $\begin{array}{l}>0.9 \\
>0.1 \\
<0.2\end{array}$ \\
\hline
\end{tabular}

TABLE 6.

\begin{tabular}{|c|c|c|c|c|c|c|c|}
\hline & \multicolumn{2}{|c|}{ Whole blood } & \multicolumn{2}{|c|}{ Plasma } & \multirow[b]{2}{*}{$\begin{array}{l}\text { Combined } \\
\text { SD }\end{array}$} & \multirow[b]{2}{*}{$t$} & \multirow[b]{2}{*}{$P$} \\
\hline & Mean & Variance & Mean & Variance & & & \\
\hline $\begin{array}{l}\text { Mobile patients } \\
\text { Immobile patients }\end{array}$ & $\begin{array}{l}51 \cdot 7 \\
51 \cdot 5\end{array}$ & $\begin{array}{l}187 \\
195\end{array}$ & $\begin{array}{l}29 \cdot 4 \\
27 \cdot 6\end{array}$ & $\begin{array}{l}148 \\
223\end{array}$ & $\begin{array}{l}12 \cdot 9 \\
14 \cdot 5\end{array}$ & $\begin{array}{l}6 \cdot 803 \\
4 \cdot 417\end{array}$ & $\begin{array}{l}<0.001 \\
<0.001\end{array}$ \\
\hline
\end{tabular}


but Bluestone, Lewis \& Mervant (1971) and Darlington et al. (1971) have shown that such therapy does not produce any significant overall fall in lipid levels.

The relationship if any between gout and cardiovascular disease remains obscure, but does not appear to be related to pathological platelet adhesiveness.

\section{Acknowledgments}

We wish to thank Miss Charis E. Jocelyn and Miss Bernedette Godhino for skilled technical help. We are grateful to the Sub-committee for Clinical Research, Charing Cross Hospital, for financial support.

\section{References}

Bluestone, R., Lewis, B. \& Mervant, I. (1971) Hyperlipoproteinaemia in gout. Annals of Rheumatic Diseases, 30, 134.

Bridges, J.M., Dalby, A.M., Millar, J.H.D. \& Weaver, J.A. (1965) An effect of D-glucose on platelet stickiness. Lancet, i, 75.

Darlington, L.G., Shaw, S. \& Scott, J.T. (1971) Plasma lipid levels and platelet adhesiveness in gout. Annals of Rheumatic Diseases, 30, 541.

Darlington, L.G. \& ScOtT, J.T. (1972) Plasma lipid levels in gout. Annals of Rheumatic Diseases, 31, 487.

FyFE, T. \& Hamilton, E. (1967) Effect of variation of the interval between venepuncture and measurement of platelet adhesiveness by the Payling Wright method. Lancet, ii, 542.
Hall, A.P. (1965) Correlations among hyperuricemia, hypercholesterolemia, coronary disease and hypertension. Arthritis and Rheumatism, 8, 846.

HoAK, J.C., WARner, E.D. \& ConNor, W.E. (1967) Platelets, $\stackrel{\text { C }}{-}$ fatty acids and thrombosis. Circulation Research, 20, 11.

Ikkala, E., Myllylä, G. \& Sarajas, H.S.S. (1966) Platelet के adhesiveness and ADP-induced platelet aggregation in $\bar{C}$ exercise. Annales medicinae experimentalis et biologiae Fenniae, 44, 88.

Kerr, J.W., MacAulay, I., Pirrie, R. \& Bronte-Stewart, $\frac{\bar{\omega}}{J}$ B. (1965) Platelet-aggregation by phospholipids and $\stackrel{\mathbb{Q}}{\square}$ free fatty acids. Lancet, i, 1296.

McDonald, L. \& EDgiLl, M. (1958) Dietary restriction and coagulability of the blood in ischaemic heart-disease. $\vec{\nabla}$ Lancet, i, 996.

Murchison, L.E. \& Fyfe, T. (1966) Effects of cigarette $\overrightarrow{\vec{\omega}}$ smoking on serum-lipids, blood-glucose, and platelet $\mathscr{\sigma}$ adhesiveness. Lancet, ii, 182.

O'Brien, J.R. (1968a) Aspirin and platelet aggregation. $\frac{3}{3}$ Lancet, i, 204.

O'Brien, J.R. (1968b) Effects of salicylates on human $\frac{\overrightarrow{0}}{0}$ platelets. Lancet, i, 779.

Pegrum, G.D., Harrison, K.M., Shaw, S., Haselton, A. \& V WolfF, S. (1967) Effect of prolonged exercise on platelet iN adhesiveness. Nature, 213, 301.

Shaw, S., Pegrum, G.D. \& Wolff, S. (1970) Estimation of platelet adhesiveness on whole blood and platelet-rich plasma. Journal of Clinical Pathology, 23, 144.

Weiss, T.E. \& Segaloff, A. (1959) Gouty Arthritis and Gout. Charles C. Thomas, Springfield, Ill.

Wright, H. PAyling. (1942) Changes in the adhesiveness of blood platelets following parturition and surgical operas $\vec{\oplus}$ tions. Journal of Pathology and Bacteriology, 54, 461 . 